\title{
MACHINE TRANSLATION IN THE FIELD OF LAW: A STUDY OF THE TRANSLATION OF ITALIAN LEGAL TEXTS INTO GERMAN
}

\author{
EVA WIESManN, Prof., PhD \\ Department of Interpreting and Translation, \\ University of Bologna \\ Corso della Repubblica 136, 47121 Forlì, Italy \\ eva.wiesmann@unibo.it
}

ORCID: https://orcid.org/0000-0001-9414-8038

\begin{abstract}
With the advent of the neural paradigm, machine translation has made another leap in quality. As a result, its use by trainee translators has increased considerably, which cannot be disregarded in translation pedagogy. However, since legal texts have features that pose major challenges to machine translation, the question arises as to what extent machine translation is now capable of translating legal texts or at least certain types of legal text into another legal language well enough so that the postediting effort is limited, and, consequently, whether a targeted use in translation pedagogy can be considered. In order to answer this question, DeepL Translator, a machine translation system, and MateCat, a CAT system that integrates machine translation, were tested. The test, undertaken at different times and without specific translation memories, provided
\end{abstract}


for the translation of several legal texts of different types utilising both systems, and was followed by systematisation of errors and evaluation of translation results. The evaluation was carried out according to the following criteria: 1) comprehensibility and meaningfulness of the target text; and 2) correspondence between source and target text in consideration of the specific translation situation. Overall, the results are considered insufficient to give post-editing of machine-translated legal texts a bigger place in translation pedagogy. As the evaluation of the correspondence between source and target text was fundamentally worse than with regard to the meaningfulness of the target text, translation pedagogy should respond by raising awareness about differences between machine translation output and human translation in this field, and by improving translation approach and strengthening legal expertise.

Key words: neural machine translation; legal translation; translation pedagogy.

\title{
MASCHINELLE ÜBERSETZUNG VON RECHTSTEXTEN: EINE STUDIE ZUR ÜBERSETZUNG AUS DEM ITALIENISCHEN INS DEUTSCHE
}

\begin{abstract}
German: Mit der Ablösung der statistischen durch die neuronale Übersetzung hat die maschinelle Übersetzung einen weiteren Qualitätssprung gemacht. Dadurch ist auch ihre Nutzung durch Übersetzerinnen und Übersetzer in der Ausbildung stark gestiegen, was bei der Ausrichtung der Didaktik und der Bewertung der studentischen Leistungen nicht unberücksichtigt bleiben kann. Da nun aber Rechtstexte Merkmale haben, die die maschinelle Übersetzung vor größere Herausforderungen stellen, fragt sich, inwieweit die maschinelle Übersetzung heute schon in der Lage ist, auch Rechtstexte oder zumindest bestimmte Textsorten oder Teile von Textsorten so gut in eine andere Rechtssprache zu übertragen, dass sich der Aufwand an Post-Editing in Grenzen hält, und ob folglich ein gezielter Einsatz in der Didaktik in Erwägung gezogen werden kann. Auf dem Prüfstand stehen zwei kostenlos online zur Verfügung stehende Systeme, DeepL Translator und MateCat. Während DeepL Translator ein reines mit Linguee trainiertes System der neuronalen maschinellen Übersetzung ist, handelt es sich bei MateCat um ein CAT-System mit Integration der zunächst statistischen und heute neuronalen maschinellen Übersetzung, das einerseits eine Nutzung eigener Ressourcen oder von MyMemory und andererseits eine Auswahl unter verschiedenen Systemen der maschinellen Übersetzung oder eine Nutzung einer Kombination von Systemen der maschinellen Übersetzung erlaubt. Das Versuchsdesign sieht die mehrfach in verschiedenen Zeitabständen
\end{abstract}


erfolgende italienisch-deutsche Übersetzung von Texten verschiedener Textsorten der Rechtsetzung (Gesetze), Rechtspraxis (notarielle Immobilienkaufverträge, Klageschriften, Gerichtsurteile, Vollmachten) und Rechtslehre (rechtswissenschaftliche Aufsätze) mit beiden Systemen und die anschließende Systematisierung der Fehler und die Bewertung der Übersetzungsergebnisse vor. Bei der Auswahl der Texte wurde nicht nur auf die Provenienz aus den verschiedenen rechtlichen Handlungsbereichen geachtet, sondern auch auf den unterschiedlichen, mit DyLan TextTools ermittelten Schwierigkeitsgrad. Die Bewertung erfolgt nach dem rein den Zieltext betreffenden Kriterium Verständlichkeit bzw. Sinnhaftigkeit und dem die Relation zwischen Ausgangstext und Zieltext betreffenden Kriterium Entsprechung unter Berücksichtigung der Übersetzungssituation. Insgesamt ist das Ergebnis noch zu schlecht, um dem Post-Editing von maschinell übersetzten Rechtstexten in der Didaktik einen größeren Platz einzuräumen. Beim rechtswissenschaftlichen Aufsatz, beim Gesetz und beim Tatbestand der Klageschrift wurden aber vergleichsweise gute Ergebnisse erzielt. Die Bewertung fiel bei der Relation zwischen Ausgangstext und Zieltext grundsätzlich schlechter als in Bezug auf die Verständlichkeit bzw. Sinnhaftigkeit des Zieltextes aus. Darauf muss die Didaktik mit einer Verbesserung des übersetzerischen Vorgehens und einer Stärkung der Fachkompetenz antworten. Außerdem muss sie das Bewusstsein für die Unterschiede zwischen Human- und maschineller Übersetzung schärfen.

Schlüsselwörter: Neuronale maschinelle Übersetzung; Rechtsübersetzung; Übersetzungsdidaktik.

\title{
PRZEKLAD MASZYNOWY W OBSZARZE PRAWA: STUDIUM PRZEKŁADU TEKSTÓW PRAWNYCH Z JĘZYKA WLOSKIEGO NA NIEMIECKI
}

\begin{abstract}
Abstrakt: W związku z poprawą jakości tłumaczenia maszynowego jest ono wykorzystywane przez adeptów sztuki przekładoznawczej w coraz to większym stopniu. Teksty prawne stanowią jednak spore wyzwanie dla przekładu maszynowego, prowadząc do rozważań nad możliwością wykorzystywania thumaczenia maszynowego właśnie do pracy nad takimi tekstami jak i nad potencjalnym zastosowaniem w nauczaniu przekładu. W celu analizy tego zagadnienia, podjęto pracę nad systemem tłumaczenia maszynowego DeepL Translator oraz systemem CAT integrującym thumaczenie maszynowe - MateCat. Badania z wykorzystaniem obu systemów przeprowadzane były $\mathrm{w}$ różnym czasie, bez określonych pamięci thumaczeniowych dla danych tekstów prawnych, dając zarazem
\end{abstract}


podstawy dla oceny wyników i uszeregowania rodzajów błędów. Ocena opierała się na określonych kryteriach: 1) zrozumienie i znaczenie tekstu docelowego; 2) relacja między tekstami wyjściowym a wejściowym w określonych sytuacjach tłumaczeniowych. Wyniki okazały się być niewystarczające do uznania za przydatne w postedycji tekstów prawnych w znacznym stopniu dla nauczania przekładu. Ocena relacji tekst wejściowy-wyjściowy była znacznie niższa niż ta dotycząca znaczenia tekstu, stąd postuluje się, że nauczanie przekładu powinno prowadzić do zwiększenia świadomości, że między rezultatem przekładem maszynowym a tłumaczeniem ludzkim występują różnice oraz usprawnień wobszarze kompetencji prawnych i prawniczych jak i w podejściu translatorskim.

Słowa klucze: neuronowe thumaczenie maszynowe (NMT); thumaczenie prawne; nauczanie przekładu.

\section{Research question and objective}

Since neural machine translation systems are freely available on the Internet, they are increasingly being used by trainee translators too. In my course in Translation from Italian into German, which is a first-year course in the BA degree program in Intercultural and Linguistic Mediation at the University of Bologna, $45.5 \%$ of the students stated at the beginning of the course in 2016/2017 that they knew something of machine translation systems. This knowledge entails, for the most part, DeepL Translator or Google Translate. In 2017/2018 and 2018/2019, machine translation systems were used in the MA degree program in Specialized Translation at the University of Bologna, inter alia, in the course in Specialized Translation from German into Italian. In this course, students have been involved in the post-editing of several kinds of machine-translated specialized (mostly non-legal) texts. Whether or not one wishes to use machine translation systems in teaching, the topic of machine translation will have to play a role in translation pedagogy because students increasingly use machine translation systems to complete their translations. In this regard, the following can be postulated:

The use of machine translation systems must not be uncritical, so a general idea of how such systems work and a requisite 
understanding of how to deal with them is essential for students. This is especially true where these systems deliver such good results that the post-editing effort is limited.

(ii) The use of machine translation systems requires the reevaluation of the impact of the different translation skills. In particular, specialized expertise should play a greater role.

(iii) When evaluating student achievement, the use of machine translation systems cannot be disregarded, especially in the case of translation from mother tongue into a foreign language.

Legal texts have always been among the most complex specialized texts (Killmann 2014, Prieto Ramos 2015 etc.). They have a range of features - with differences related to legal systems, branches of law and text types - that still pose major challenges to machine translation. First, they are characterized by all the features that are a challenge to machine translation generally. Matthiesen (2017: 44-6) names the following:

(i) syntactic complexity (sentence length, hypotactic structures, number of clause elements and complexity of the modifiers),

(ii) lexical and syntactic (but also the pragmatic and referential) ambiguity,

(iii) phraseology,

(iv) divergences at lexical and structural level,

(v) errors in the source text. ${ }^{1}$

Secondly, there are at least the following features that are likely to cause machine translation problems, as the author will show later by means of examples:

(i) terminology, which is always bound to legal systems and often attributes legal meanings to words and phrases of common language usage,

(ii) abbreviations that occur in large numbers and where a full stop runs the risk of being interpreted as a sentence boundary,

(iii) formulaic usage,

(iv) elliptical usage as a special form of formulaic usage,

(v) text type-specific deviations from normal language usage.

Therefore, the question arises as to what extent machine translation is already capable of translating legal texts or, at least,

\footnotetext{
${ }^{1}$ Errors in the source text are not often mentioned in the literature on legal texts, but they do occur in practice, as relevant translation experience proves.
} 
certain types of text or parts thereof into another legal language well enough so that the post-editing effort is limited. The author hypothesizes that the development of machine translation in this regard has not progressed far enough to translate legal texts, in view of the features mentioned above, without a major post-editing effort. This hypothesis will be verified in the present article in order to find out how much of a role machine translation should currently play in an MA course in Specialized Translation from Italian into German, which - unlike its counterpart Specialized Translation from German into Italian - deals only with legal translation. In this context, postediting is not to be understood as a light post-editing but as a full postediting that complies with DIN EN ISO 18587 (Wallberg 2017) and meets the requirements of the translation tasks. With such postediting, only stylistic imperfections are accepted as long as the target text still reads fluently (Hansen-Schirra et al. 2017: 178).

After a brief overview of the various methods and systems of machine translation, the test design, which serves to verify the research hypothesis, is presented. The test, described in more detail below, provides for the translation from Italian into German of several legal texts of different types utilizing a pure machine translation system (DeepL Translator) and a system integrating machine translation (MateCat). It was followed by systematization of errors produced by these systems and evaluation of translation results on the basis of the criteria previously established. In the conclusion, the considerations and implications for translation pedagogy are discussed.

\section{Methods and systems of machine translation in comparison}

\section{Development of machine translation}

The history of machine translation dates back to the 1930s (Burchardt and Porsiel 2017: 12). Until the end of the 80s, machine translation was rule-based (Hutchins 1995: 440). It implied a phase of more or 
less elaborate analysis of the source text and a phase of target text synthesis and could involve a transfer phase. Matthiesen (2017: 2832) distinguishes three approaches within rule-based machine translation: 1) direct translation, 2) transfer-based translation, and 3) interlingua-based or indirect translation. In the case of direct translation, the target text was generated directly from the source text with little or no linguistic (namely morphological) analysis and with the aid of a bilingual dictionary. The translation took place at the word level. Transfer-based translation implied a comparatively more complex but not full linguistic (namely morphological, syntactic, and semantic) analysis of the source text, resulting in an abstract source text representation. This was then converted into a target text representation, from which finally the target text was generated and syntactically adjusted. In interlingua-based translation, a full linguistic analysis of the source text was made and a complete abstract interlingual representation was created, which could then be used for synthesis. This interlingual representation was theoretically universally applicable, but on a practical level it could only be realized to a limited extent.

The next period of machine translation, starting at the beginning of the 1990s, was dominated by statistical machine translation in which a distinction can be made between 1) purely statistical machine translation and 2) example-based machine translation (Matthiesen 2017: 33-6). In contrast to rule-based machine translation, statistical machine translation works with information from aligned parallel corpora, so it is corpus-based. In example-based machine translation, only sentences and parts of sentences existing in the corpus are retrieved and used for translation (Werthmann and Witt 2014: 96). If no matches are found, there is no translation output. Purely statistical machine translation has evolved from wordbased to phrase-based machine translation. From a large number of segments of translation corpora and monolingual corpora, a system is built from which a translation model and a target language model are developed. The training phase of the system is followed by the fine-tuning phase with respect to a specific subject area (technical, medical, economic etc) and the test phase. Statistical machine translation is based on statistical probability calculations and involves a two-step process (Koehn 2010: 63-78). In the first step, the translation model is used to determine probable correspondences in the target language for the elements of the source 
language. In the second step, the most probable translations for the context are selected using the language model of the target language and the most probable word order in the target language is generated.

The most recent and promising method of machine translation is neural machine translation, whose peculiarity is that it works with artificial neural networks, thus making use of artificial intelligence. It incorporates large knowledge databases for extra-linguistic world knowledge, but also for language-independent representations of text meaning. The process of translation in a neural machine translation system is the following (Forcada 2017): An appropriately trained artificial neural network (encoder) processes the source sentence word by word and transposes it into a mathematical representation in which each word is represented in the context of the sentence as a multidimensional vector. From this abstract representation another artificial neural network (decoder) generates word by word the target-language sentence. To train the system, built from a large number of translation corpora segments, from which a translation model is developed, machine learning is used. An adaptive neural machine translation can also learn from the post-editing of translators, whereby it applies changes made by the translator, for example, to a legal term automatically to the rest of the text wherever that term appears.

While rule-based machine translation no longer plays a role today, neural machine translation has not quite displaced statistical machine translation. As pointed out by Castilho et al. (2017: 117-8), neural machine translation undoubtedly represents a step forward for the field of machine translation but, depending on the subject area and the language pair, statistical machine translation can produce better translations. The characteristic feature of neural machine translation is that it usually produces fluent (i.e., understandable and meaningful) texts in which errors (i.e., the non-correspondence between the source text and the target text) are therefore harder to find. However, the typical errors of neural machine translation are usually immediately apparent. These include (van Brussel et al. 2018):

(i) case sensitivity,

(ii) word repetitions,

(iii) word omissions,

(iv) word additions, 
(v) words that make no sense in context,

(vi) terminological inconsistency,

(vii) wrong numbers.

\section{DeepL Translator vs. MateCat}

The systems selected for our test were DeepL Translator, a neural machine translation system, and MateCat, a CAT system that integrates machine translation. While the decision to select DeepL Translator is due to the fact that this machine translation system challenged the market position of the previous leader Google Translate (Kyburz 2018), MateCat was chosen because it allows to use a combination of machine translation systems.

Deepl Translator is a service of the German company DeepL, which was founded in 2009 under the name Linguee. Since August 2017, this neural machine translation system is available online for free. In March 2018, the subscription service DeepL Pro was introduced, which presents itself as an optimized web translator and in contrast to the free service - allows to integrate SDL Trados Studio and other CAT tools. The neural machine translation system was trained with the translation memory Linguee, which can still be used in addition to DeepL Translator. The source language is automatically recognized by Deepl Translator. The freely combinable languages are now nine (German, English, French, Italian, Dutch, Polish, Portuguese, Russian, Spanish). Originally, the source text could only be copied into an input-mask and could not contain more than 5,000 characters. When entering the mask, the source text formatting was completely lost. The target text was always displayed in the output-mask next to it. Now the restriction in the text volume is lifted and the source text can also be uploaded as a file. This preserves the formatting in the target text, which can then be downloaded as a file.

MateCat is the result of a research project undertaken by: the international research center "Fondazione Bruno Kessler", the translation service provider Translated.net, the Université du Maine and the University of Edinburgh. This CAT system first used statistical machine translation. In November 2016, the switch 
to neural machine translation occurred. The system has been available online since 2014 for free and is based on Google Chrome or Safari. It can be used both with and without registration. When using it with registration, it is possible to include the translator's own translation memories and other resources (especially glossaries), when using it without registration, the translation memory "My Memory" is used. As far as the machine translation component is concerned, MateCat gives the user the following options:

(i) choice of one of the integrated machine translation systems (Google Translate, ModernMT, Yandex Translate etc.), or

(ii) use of a combination of machine translation systems (at the time of the test, these were: Google Translate, DeepL Translator and Microsoft Translator), or

(iii) refrain from using a machine translation system.

The freely combinable languages are presently 209 . The source text is not entered in a form, but always uploaded as a file. In this way, the formatting of the source text is completely preserved in the target text, which can also be downloaded as a file. Each translation can be downloaded as a preview file before any changes are made.

\section{Machine translation of legal texts}

\section{Previous studies}

Some studies are already available on the use of machine translation systems for the translation of legal texts. To the author's knowledge, however, these mostly concern the use of statistical systems. Yates (2006) examines the accuracy of Babel Fish in translating texts of interest to law libarians and law library users. In this context, she concentrates on Babel Fish's output in English for portions of Mexico and Germany's civil codes. The purpose of her study was to determine whether Babel Fish produces translations accurate enough for law libarians and law library users so that they can grasp the general intent of the original texts. Because of the severe errors that altered the meaning of such texts, she concludes that Babel Fish is not appropriate for most uses in law libraries. Killman (2014), 
on the other hand, examines the accuracy of Google Translate output in English for a large sample of legal vocabulary items from a collection of judgment summaries produced by the Supreme Court of Spain. He found that Google Translate provided for accurate translations in slightly over $64 \%$ of the cases and demonstrates that the machine translation system performs consistently well in the translation of legal vocabulary. Finally, Şahin and Dungan (2014) have explored students' use of time, performance and reaction when they translate technical, literary, media and also legal texts from English into Turkish using either only printed resources or only online resources or post-editing target texts produced via Google Translate, thus, seeing in which contexts students feel better and can achieve better results when tested. The legal text used in their study was an extract from the Treaty on the European Union. The analysis of the questionnaires completed by the participants and the evaluations of the translations suggested that novice translators did not seem to be very comfortable with post-editing machine translation outputs and that the perceived difficulty level of the texts seemed to have more effect on the time use and performance of translators than the type of resource used. Indeed, more time was needed for the translation of the legal text, which was reported by the participants as the most difficult.

The only study that, to my knowledge, takes legal texts into account in exploring the use of neural machine translation systems is that of Heiss and Soffritti (2018). These authors examine the effects of the availability of DeepL Translator on the teaching of translation of specialized and non-specialized texts from Italian into German. Their analysis of quality levels of DeepL Translator's raw output and successive improvements with post-editing leads to the conclusion that the results are quite promising, also with regard to legal texts. As in our study, the legal text involved in analysis is an excerpt from a law. So their results can be compared to ours.

\section{Test design}

In contrast to the previous studies, we focus on translation of legal texts and neural machine translation. The aim of our test was to find 
out to what extent machine translation, and indeed neural machine translation, is already capable of translating legal texts or at least certain types of text or parts thereof into another legal language well enough so that the post-editing effort is limited. With regard to the following question, how much of a role machine translation should play in the course in Specialized Translation from Italian into German at the University of Bologna, the legal languages involved in the test were Italian as source language and German as target language. The texts were selected from three major areas of legal activity (legislative area, area of legal practice, area of legal theory), which also correspond to important areas of translation practice. As a typical representative of the legislative area, a law, or rather an excerpt from a law, was selected; and as a typical representative of the area of legal theory, a legal essay was chosen. Several texts were selected from the area of legal practice, namely: a power of attorney, a notarial real estate sale contract, a statement of claim and a civil court judgment, which are frequently-translated text types. The length of the source texts, in terms of number of words and sentences and number of words per sentence, was variable. The level of difficulty, established with DyLan TextTools, was above $80 \%$ for all texts apart from the statement of claim (fig. 1). ${ }^{2}$ Text length and level of difficulty were later related to the test results.

Fig. 1. Length and level of difficulty of the test texts.

\begin{tabular}{|l|l|l|l|l|}
\hline \multicolumn{2}{|l|}{ text types } & \multicolumn{2}{|l|}{ text length } & $\begin{array}{l}\text { level of } \\
\text { difficulty }\end{array}$ \\
\hline law (excerpt) & $\begin{array}{l}2,328 \\
\text { words }\end{array}$ & $\begin{array}{l}96 \\
\text { sentences }\end{array}$ & $\begin{array}{l}24.3 \\
\text { words/ } \\
\text { sentence }\end{array}$ & $96.1 \%$ \\
\hline power of attorney & 412 words & 4 sentences & $\begin{array}{l}103.0 \\
\text { words/ } \\
\text { sentence }\end{array}$ & $83.0 \%$ \\
\hline
\end{tabular}

2 Dylan TextTools is an instrument of the Italian Istituto di Linguistica Computazionale "Antonio Zampolli" based on the Gulpease Index, an index of readability of a text calibrated on the Italian language. 
Comparative Legilinguistics 37/2019

\begin{tabular}{|l|l|l|l|l|}
\hline $\begin{array}{l}\text { notarial real estate } \\
\text { sale contract }\end{array}$ & $\begin{array}{l}1,338 \\
\text { words }\end{array}$ & $\begin{array}{l}22 \\
\text { sentences }\end{array}$ & $\begin{array}{l}60.8 \\
\text { words/ } \\
\text { sentence }\end{array}$ & $83.3 \%$ \\
\hline statement of claim & $\begin{array}{l}1,563 \\
\text { words }\end{array}$ & $\begin{array}{l}47 \\
\text { sentences }\end{array}$ & $\begin{array}{l}33.3 \\
\text { words/ } \\
\text { sentence }\end{array}$ & $69.9 \%$ \\
\hline $\begin{array}{l}\text { civil } \\
\text { judgment }\end{array}$ & $\begin{array}{l}1,627 \\
\text { words }\end{array}$ & $\begin{array}{l}28 \\
\text { sentences }\end{array}$ & $\begin{array}{l}\text { words/ } \\
\text { sentence }\end{array}$ & $81.4 \%$ \\
\hline legal essay & $\begin{array}{l}2,650 \\
\text { words }\end{array}$ & $\begin{array}{l}64 \\
\text { sentences }\end{array}$ & $\begin{array}{l}\text { words/ } \\
\text { sentence }\end{array}$ & $99.5 \%$ \\
\hline
\end{tabular}

In addition, given the rapid development of the machine translation industry, which makes an improvement in quality likely, it seemed useful not only to compare different systems, but also to repeat the test after a certain period of time with these systems. For the reasons mentioned above, the systems DeepL Translator and MateCat were selected. MateCat was used with a combination of Google Translate, DeepL Translator and Microsoft Translator. As period between the two test times, four months were considered sufficient to detect possible developments. As far as DeepL Translator is concerned, the first test time was before the introduction of the subscription service DeepL Pro, and the second test time after, so that it was also possible to find out whether the introduction of the subscription service would lead to a deterioration of the output quality of the free service or not (fig. 2). 
Fig. 2. Test Design.

\begin{tabular}{|l|l|l|l|l|l|}
\hline & $\begin{array}{l}\text { DeepL Translator } \\
\text { 09/01/2018 }\end{array}$ & $\begin{array}{l}\text { DeepL Translator } \\
10 / 05 / 018\end{array}$ & $\begin{array}{l}\text { MateCAT } \\
\text { 09/01/2018 }\end{array}$ & $\begin{array}{l}\text { MateCAT } \\
10 / 05 / 2018\end{array}$ \\
\hline legislation & law & \\
\hline \multirow{4}{*}{ legal practice } & power of attorney \\
\cline { 2 - 2 } & contract & statement of claim \\
\cline { 2 - 3 } & court judgment & \\
\hline \multirow{2}{*}{ legal theory } & essay &
\end{tabular}

For the test in which all translations were manually analyzed and subsequently evaluated by the author, the evaluation criteria are given by the statement made above that the neural machine translation mostly produces fluent (i.e., understandable and meaningful) texts in which the errors (i.e., the noncorrespondence between source text and target text) are harder to find. This is precisely what can lead to an uncritical use of machine translation systems by students, especially when translating into a foreign language. The evaluation criteria "comprehensibility/meaningfulness of the target text" and "correspondence between source and target text" correspond to the branches "fluency" and "accuracy" of the multidimensional quality metrics defined in Burchardt et al. (2014):

"Accuracy contains issue types that relate to the relationship of the content of the source and target texts to each other. (Note: In many contexts, Accuracy is referred to as "Adequacy." [...]) Example: A source text states that a mechanical component is made of brass and is 25 centimeters long, but the translation states that it is made of bronze and is 25 inches long.

Fluency contains issue types that relate to the linguistic wellformedness of the target (or source) text, regardless of the status of the text as a translation. In principle fluency issues can be detected by monolingual individuals examining the text with no reference to another language version. Example: A text accurately translates source-language content but has grammatical and spelling problems."

The evaluation category "comprehensibility/meaningfulness" (like the category "fluency") was applied to the target texts only. In this regard, the morphological, syntactic, lexical and semantic correctness of the target-language version were evaluated. The marks 
assigned in this category for each sentence of the translated legal texts were $0-3$, which allows a degree of differentiation that is compatible with manual analysis. By contrast, in the evaluation category "correspondence between source and target text" (like in the category "accuracy"), both the source and target texts were compared in consideration of the specific translation situation. The evaluation concerned the semantic and pragmatic counterparts, both at the level of concepts and text-type conventions, depending on the given translation situation. In this category the marks assigned were also 0 3. In order to objectify the assignment of marks, the distinctions mentioned in fig. 3 were made.

Fig. 3. Evaluation grid.

\begin{tabular}{|l|l|l|}
\hline & $\begin{array}{l}\text { comprehensibility } \\
\text { meaningfulness of the target } \\
\text { text }\end{array}$ & $\begin{array}{l}\text { correspondence between } \\
\text { source and target text } \\
\text { in consideration of the specific } \\
\text { translation situation }\end{array}$ \\
\hline $\mathbf{0}$ & $\begin{array}{l}\text { completely incomprehensible, } \\
\text { no reconstructible sense }\end{array}$ & $\begin{array}{l}\text { no correspondence between } \\
\text { source and target text }\end{array}$ \\
\hline $\mathbf{1}$ & $\begin{array}{l}\text { multiple / serious vocabulary } \\
\text { and/or grammatical errors, only } \\
\text { partially reconstructible sense }\end{array}$ & $\begin{array}{l}\text { minor correspondence between } \\
\text { source and target text, sense } \\
\text { is adequately translated } \\
\text { to a small extent }\end{array}$ \\
\hline $\mathbf{2}$ & $\begin{array}{l}\text { few / minor vocabulary and/or } \\
\text { grammatical errors, mostly } \\
\text { reconstructable sense }\end{array}$ & $\begin{array}{l}\text { large correspondence between } \\
\text { source and target text, sense } \\
\text { is adequately translated } \\
\text { to a large extent }\end{array}$ \\
\hline $\mathbf{3}$ & $\begin{array}{l}\text { completely understandable and } \\
\text { meaningful }\end{array}$ & $\begin{array}{l}\text { comprehensive correspondence } \\
\text { between source and target text }\end{array}$ \\
\hline
\end{tabular}

With regard to the specific translation situation, the different text types have partly varying translation purposes and recipients. The texts of the types power of attorney, real estate sale contract, statement of claim and civil court judgment, anchored in the Italian legal system, should be translated for a recipient of the Federal German legal system for the purpose of informing the target-culture recipient about the content of the source texts concerning them. 
The target texts therefore serve only as an aid to understanding, while the source texts remain the only legally binding texts. The translation of the legal essay relating to the Italian legal system should also serve the sole purpose of enabling the recipient of the German legal system to understand the source text in his own legal language. In contrast to the texts of legal practice, however, the text of the area of legal theory, like its translation, has a purely informative function. The situation is different in the case of the law relating to the Italian legal system. Exactly as in Heiss and Soffritti (2018), this should be translated for recipients from the German-speaking part of Italy, i.e. South Tyrol, in order to form the basis for application and interpretation alongside the Italian text. On the conceptual level, there are denominations for all terms in Italian and German. In all other texts not only the denominations differ, but to a greater or lesser extent also the concepts. An adequate representation of sense therefore means, on the terminological level, that the terms standardized for South Tyrol must be used for translation of the law selected for the test, whereas for translation of all other test texts, the terms of the Federal Republic of Germany (whose concepts are at least partially equivalent to the Italian concepts) must be used.

\section{Test results}

Before considering the different categories of errors, the results of the experiment will be presented in relation to the two categories of the evaluation grid.

Overall, as shown in fig. $4-7,,^{3}$ the results were poor, but comparatively better results were obtained for some text types and parts thereof. The percentage rates were calculated in both evaluation categories by relating the average marks assigned to the sentences of each text (or part of text) to the maximum marks attainable for the sentences of each text (or part of text). In the evaluation category "comprehensibility/meaningfulness", the best results were achieved in the legal essay and, as to DeepL

\footnotetext{
${ }^{3}$ D 9-1 = translated with DeepL Translator on January 9th, 2018; D 10-5 = translated with DeepL Translator on May 10th, 2018; M 9-1 = translated with MateCat on January 9th, 2018; M 10-5 = translated with MateCat on May 10th, 2018.
} 
Translator, in the law (fig. 4). Even in the statement of claim, especially in the description of material facts, the result was good (fig. 4 and 6). In the evaluation category "correspondence between source and target text" (fig. 5 and 7), the results were always worse than in the category "comprehensibility/meaningfulness". Here, too, the legal essay and, as to DeepL Translator, the law was positioned at the top, followed by the statement of claim, especially in relation to the description of material facts. This result is remarkable given that the level of difficulty found with DyLan TextTools was the highest in the legal essay and the law but the lowest in the statement of claim (fig. 1). Such a result may well be attributable to the length of sentences in test texts, which was shortest in the law, the statement of claim and the legal essay (fig. 1). However, as far as the law is concerned, there are major differences between the output of DeepL Translator and MateCat. Heiss and Soffritti (2018), who concentrate on the correspondence between source and target text, come to a similar conclusion with regard to the law. However, they do not make any comparison with other kinds of legal texts. This is probably the reason for their optimistic assessment of the performance of DeepL Translator with regard to legal texts. The comparatively poorer results achieved in the power of attorney, the contract, the court judgment and the part of the statement of claim other than the description of the material facts (fig. 4 - 7) are certainly also due to their stronger characterization by the above mentioned features which notoriously or, in relation to legal texts, presumably, present challenges to machine translation. Among these characteristics, the syntactic complexity and the formulaic and elliptical usage, the specific features of the text types (e.g., one-sentence structures) and the numerous abbreviations must be mentioned. 
Eva Wiesmann: Machine Translation in...

Fig. 4. Comprehensibility/meaningfulness of the target texts.

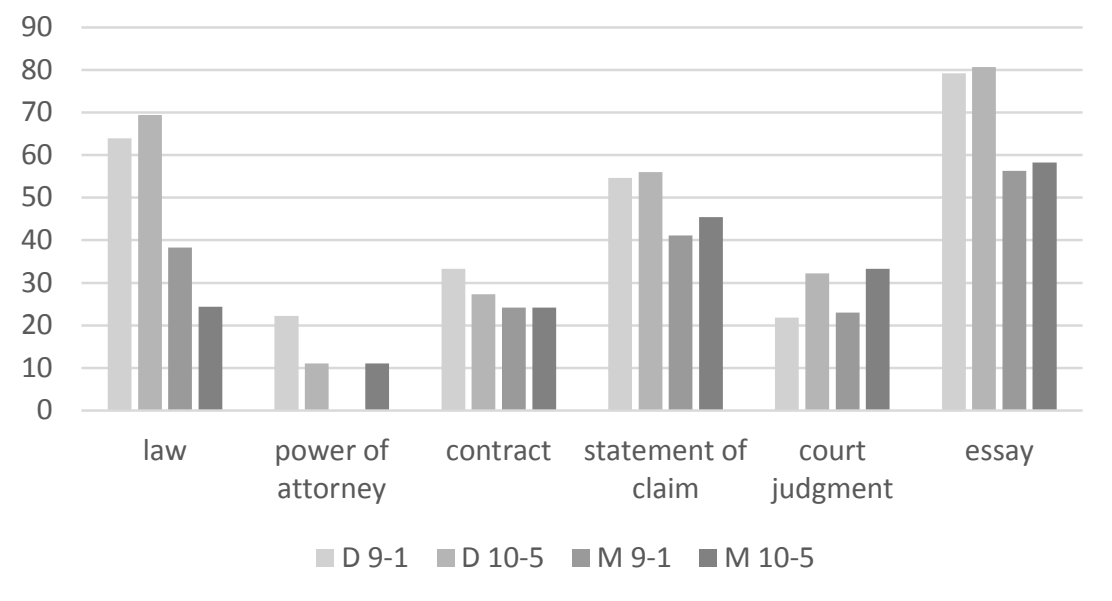

Fig. 5. Correspondence between source and target texts in consideration of the specific translation situation.

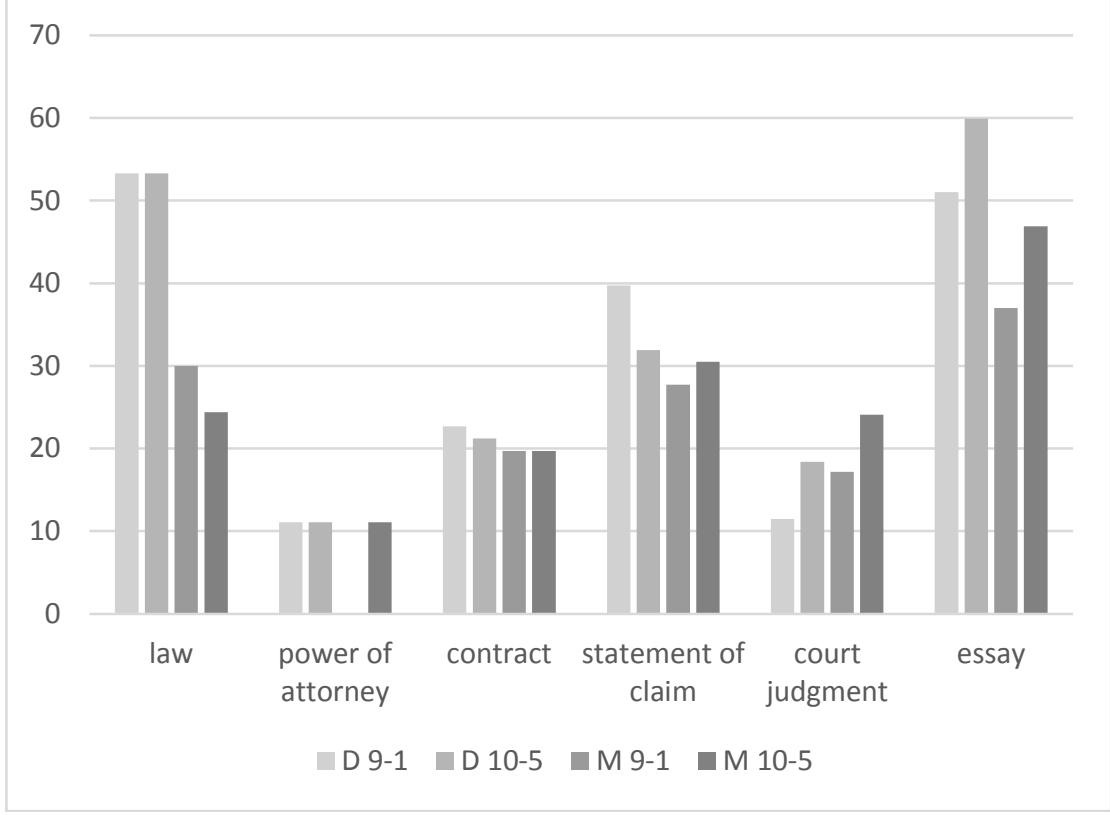


Fig. 6. "Comprehensibility/meaningfulness": single parts of the statement of claim.

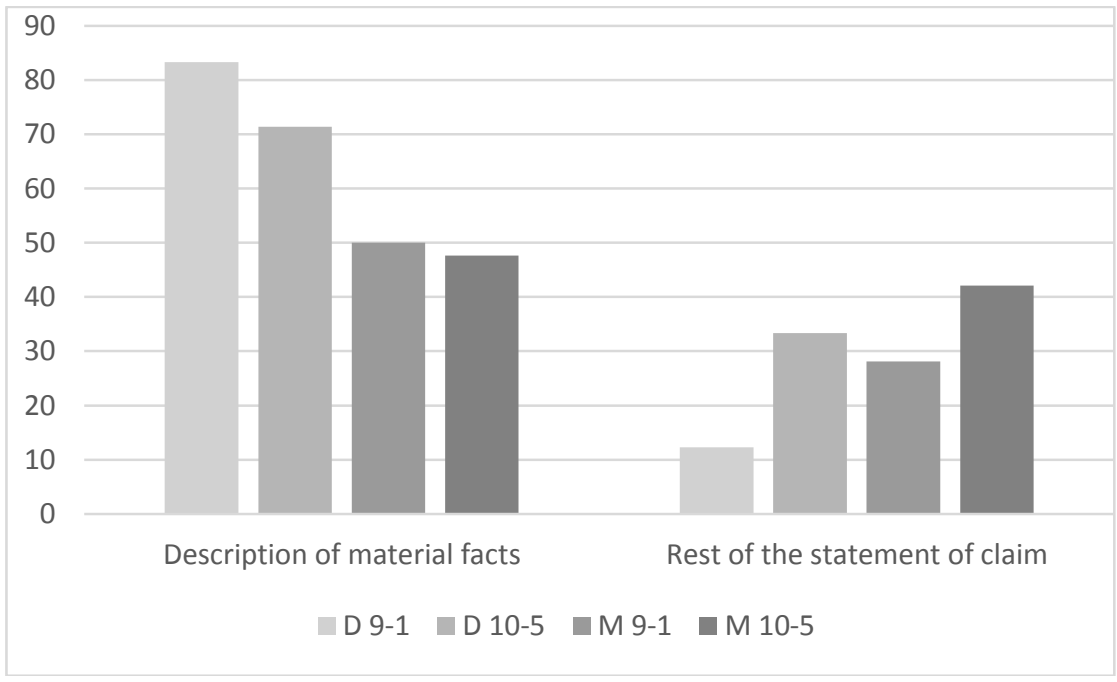

Fig. 7. "Correspondence between source and target text": single parts of the statement of claim.

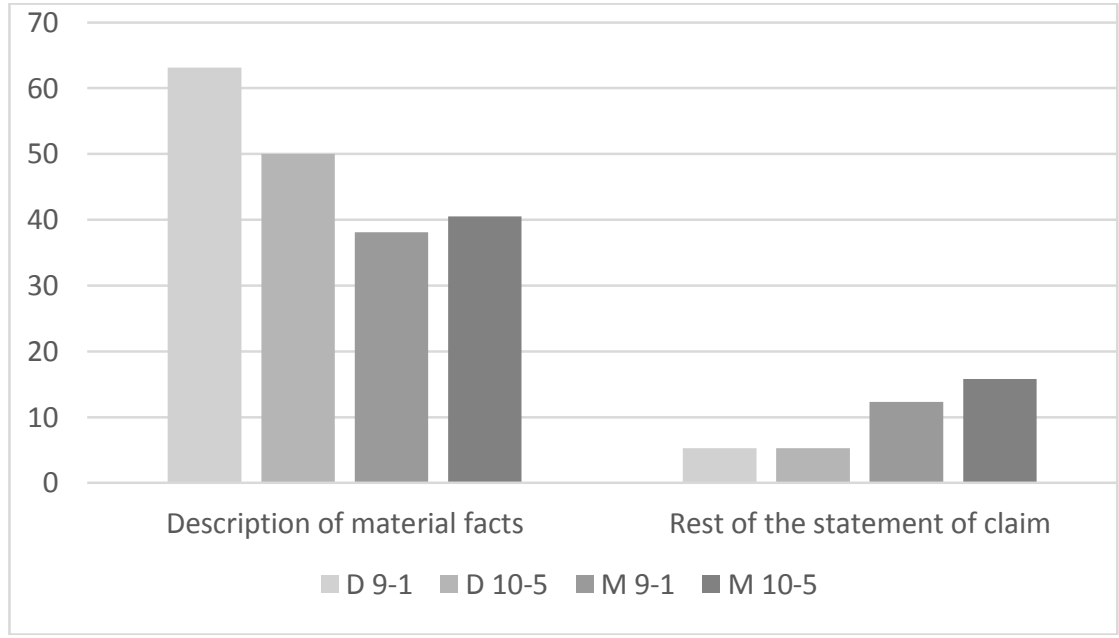

As the figures show, DeepL Translator generally performed better than MateCat. Only in the court judgment, especially in the procedural formulas, and in the parts of the statement of claim other than the description of material facts, the results were better with MateCat. Another positive feature of MateCat is the conservation 
of the layout, which was not possible at the two test times of DeepL Translator. In terms of all text types, both systems experienced improvement and deterioration (fig. $4-7$ ), so there was no clear trend of development. However, the introduction of the subscription service DeepL Pro has evidently not led to a worsening of the free service DeepL.

In total, 28 different error categories could be detected. These are listed below and then subsequently illustrated by examples from the texts, indicated in parentheses, whose translations have been analyzed. For a better understanding, a translation into English and a comment on the translation from Italian into German are provided.

Error categories:

(i) non-translation of sentences and phrases,

(ii) non-translation of words,

(iii) non-translation or incorrect translation of abbreviations,

(iv) translation of proper names,

(v) words that do not make sense in context,

(vi) English words,

(vii) word omissions,

(viii) word repetitions,

(ix) translation of partial synonyms linked by "and" with the same term,

(x) repetition of letters and letter sequences,

(xi) terminology,

(xii) terminological inconsistency,

(xiii) unexplainable additions,

(xiv) word sequences without syntactic interrelationship,

(xv) sense-changing sentence separations,

(xvi) wrong syntactic interpretation,

(xvii) misinterpretation of the syntax in case of clause elements after colon,

(xviii) wrong references,

(xix) wrong interpretation of anaphors,

(xx) wrong word order,

(xxi) tempus errors,

(xxii) misinterpretation of certain grammatical structures of Italian (si passivante, absolute participle constructions, position of the genitive attribute), 
(xxiii) wrong adjective interpretation when the adjective corresponds to a noun with an identical form,

(xxiv) formulaic usage,

(xxv) elliptical usage,

(xxvi) morphological problems,

(xxvii) non-recognition of text-specific deviations from normal language usage,

(xxviii) problems with specific drafting and text type conventions.

The non-translation of sentences and phrases (i) was mainly observed in MateCat. It manifests itself in the target text as in ex. 1.

Ex. 1 (all texts).

$[\ldots] \quad|| \quad$ UNTRANSLATED_CONTENT_START $\quad \| \quad[\ldots] \quad$ III UNTRANSLATED_CONTENT_END $\| \mid[\ldots]$.

Non-translated words (ii), underlined in ex. 2, occured in both the translations of DeepL Translator and MateCat.

Ex. 2 (civil court judgment).

\begin{tabular}{|l|l|}
\hline source text & $\begin{array}{l}\text { IL TRIBUNALE CIVILE E PENALE } \\
\text { DI VERONA SEZIONE PRIMA }\end{array}$ \\
\hline target text & $\begin{array}{l}\text { DAS ZIVIL- UND STRAFGERICHT } \\
\text { VON VERONA SEZIONE PRIMA }\end{array}$ \\
\hline $\begin{array}{l}\text { English translation } \\
\text { of the source text } \\
\text { example }\end{array}$ & $\begin{array}{l}\text { THE CIVIL AND CRIMINAL COURT } \\
\text { OF VERONA FIRST SECTION }\end{array}$ \\
\hline
\end{tabular}

Also, the non-translation or incorrect translation of abbreviations (iii; ex. 3) occurs both in the translations of DeepL Translator and MateCat.

Ex. 3 (statement of claim, civil court judgment).

\begin{tabular}{|l|l|}
\hline \hline source text & c.p.c. \\
\hline target text & italienisches Strafgesetzbuch \\
\hline
\end{tabular}


Eva Wiesmann: Machine Translation in...

\begin{tabular}{|l|l|}
\hline $\begin{array}{l}\text { English translation of } \\
\text { the source text } \\
\text { example }\end{array}$ & Italian Code of Civil Procedure \\
\hline $\begin{array}{l}\text { comment on the } \\
\text { German translation }\end{array}$ & $\begin{array}{l}\text { translation with "Italian Code of Criminal } \\
\text { Procedure" }\end{array}$ \\
\hline
\end{tabular}

Another category of errors is the translation of proper names (iv; ex. 4). This error occurs more frequently with MateCat than with DeepL Translator.

Ex. 4 (statement of claim).

\begin{tabular}{|l|l|}
\hline \hline source text & Elisabetta \\
\hline target text & Elisabeth \\
\hline
\end{tabular}

Words that do not make sense in context (v; ex. 5) are among the characteristic errors of neural machine translation. Errors of this kind occur in fact in both systems with which the test was carried out.

Ex. 5 (statement of claim: description of material facts).

\begin{tabular}{|l|l|}
\hline \hline source text & espone \\
\hline target text & entlarvt \\
\hline $\begin{array}{l}\text { English translation of } \\
\text { the source text } \\
\text { example }\end{array}$ & states \\
\hline $\begin{array}{l}\text { comment on the } \\
\text { German translation }\end{array}$ & $\begin{array}{l}\text { translation with "unmaskes". Since the verb } \\
\text { facts, "entlarvt" ("unmaskes") does not make } \\
\text { sense in this context. }\end{array}$ \\
\hline
\end{tabular}

Another category of errors that are more common with DeepL Translator are English words (vi; ex. 6), which do not make sense in a translation from Italian into German. 
Ex. 6 (power of attorney).

\begin{tabular}{|l|l|}
\hline \hline source text & procura speciale \\
\hline target text & special power \\
\hline $\begin{array}{l}\text { English translation of } \\
\text { the source text } \\
\text { example }\end{array}$ & special power of attorney \\
\hline
\end{tabular}

Word omissions (vii; ex. 7) occur in both DeepL Translator and MateCat, and the same applies to word repetitions (viii; ex. 8). In both cases, these are characteristic errors of neural machine translation. The omitted or repeated words in the target texts are underlined in the examples.

Ex. 7 (statement of claim).

\begin{tabular}{|l|l|}
\hline \hline source text & inademplendi non est ademplendum \\
\hline target text & non est ademplendum \\
\hline
\end{tabular}

Ex. 8 (civil court judgment).

\begin{tabular}{|l|l|}
\hline \hline source text & $\begin{array}{l}\text { posto che l'obbligazione restitutoria }[\ldots] \\
\text { costituisce }[\ldots]\end{array}$ \\
\hline target text & $\begin{array}{l}\text { da es sich bei der bei der Rückzahlung um }[\ldots] \\
\text { handelt }\end{array}$ \\
\hline
\end{tabular}

Also, the error which consists in the translation of partial synonyms linked by "and" (underlined in target text) with the same term (ix) occurs in both systems (ex. 9). The same applies to the repetition of letters and letter sequences (x; ex. 10).

Ex. 9 (statement of claim).

\begin{tabular}{|l|l|}
\hline \hline source text & presenza di vizi e difetti \\
\hline target text & Vorhandensein von Mängeln und Mängeln \\
\hline
\end{tabular}


Eva Wiesmann: Machine Translation in...

\begin{tabular}{|l|l|}
\hline $\begin{array}{l}\text { English translation of } \\
\text { the source text } \\
\text { example }\end{array}$ & presence of defects and deficiencies \\
\hline
\end{tabular}

Ex. 10 (statement of claim).

\begin{tabular}{|l|l|}
\hline \hline source text & CCTTUU \\
\hline target text & CCTTUUUUU \\
\hline $\begin{array}{l}\text { English translation of } \\
\text { the source text } \\
\text { example }\end{array}$ & forensic expert reports \\
\hline $\begin{array}{l}\text { comment on the } \\
\text { German translation }\end{array}$ & $\begin{array}{l}\text { In Italian, the repetition of letters is commonly } \\
\text { used to render the singular form of an acronym } \\
\text { (in the example: CTU = consulenza tecnica } \\
\text { d'ufficio) in the plural (CCTTUU). }\end{array}$ \\
\hline
\end{tabular}

Examples of terminology errors (xi; ex. 11) are common in all text types and are frequent in Deepl Translator and MateCat.

Ex. 11 (legal essay).

\begin{tabular}{|l|l|}
\hline \hline source text & società di capitali \\
\hline target text & Gesellschaften mit beschränkter Haftung \\
\hline $\begin{array}{l}\text { English translation of } \\
\text { the source text } \\
\text { example }\end{array}$ & corporations \\
\hline $\begin{array}{l}\text { comment on the } \\
\text { German translation }\end{array}$ & $\begin{array}{l}\text { Instead of using the hyperonym, a hyponym was } \\
\text { used in the target text. }\end{array}$ \\
\hline
\end{tabular}

Another characteristic error of neural machine translation that occurs in both systems is terminological inconsistency (xii; ex. 12). 
Ex. 12 (power of attorney).

\begin{tabular}{|c|c|}
\hline source text & scrittura privata $[\ldots]$ scrittura privata \\
\hline target text & Privatvereinbarung $[\ldots]$ Privatvertrag \\
\hline $\begin{array}{l}\text { English translation of } \\
\text { the source text } \\
\text { example }\end{array}$ & $\begin{array}{l}\text { privately executed agreement }[\ldots] \text { privately } \\
\text { executed agreement }\end{array}$ \\
\hline
\end{tabular}

Additions for which there is no explanation (xiii; underlined in ex. 13) can be found in both DeepL Translator and MateCat and the same applies to word sequences without syntactic interrelationship (xiv; ex. 14).

\section{Ex. 13 (civil court judgment).}

\begin{tabular}{|c|c|}
\hline source text & $\begin{array}{l}\text { Orbene, ai fini della decisione, va innanzi tutto } \\
\text { esaminata la contestazione di inammissibilità } \\
\text { della domanda principale degli attori, formulata } \\
\text { dai convenuti sul presupposto dell'omessa } \\
\text { formulazione di un vero e proprio } \\
\text { disconoscimento (o mancato riconoscimento) } \\
\text { ai sensi dell'art. } 214 \text { c.p.c. della scrittura- } \\
\text { testamento e dell'omessa produzione in giudizio } \\
\text { dell'originale di quest'ultima. }\end{array}$ \\
\hline target text & $\begin{array}{l}\text { Für die Zwecke der Entscheidung ist zunächst } \\
\text { die Behauptung } \text { zu prüfen, } \\
\text { die Hauptforderung der Kläger, die von } \\
\text { den Beklagten auf der } \\
\text { der Nichtformulierung Grundlage } \\
\text { Nichtanerkennung (oder Nichtanerkennung) } \\
\text { im Sinne von Artikel } 81 \text { Absatz } 1 \text { EG-Vertrag } \\
\text { erhoben wurde, unzulässig ist. } 214 \text { c.p.c. } \\
\text { der Schreibprüfung und unterlassene Herstellung } \\
\text { in Gerichtsverfahren des Originals der letzteren. }\end{array}$ \\
\hline $\begin{array}{l}\text { English translation of } \\
\text { the source text } \\
\text { example }\end{array}$ & $\begin{array}{l}\text { For the purposes of the court's decision, first } \\
\text { of all, it is necessary to examine the allegation } \\
\text { of inadmissibility of the plaintiffs' main claim, } \\
\text { made by the defendants on the basis } \\
\text { of the omitted formulation of a veritable } \\
\text { repudiation (or non-recognition) of the will }\end{array}$ \\
\hline
\end{tabular}




\begin{tabular}{|l|l|}
\hline & $\begin{array}{l}\text { in accordance with Article 214 of the Code } \\
\text { of Civil Procedure and the omitted presentation } \\
\text { of the original of the will during the proceedings. }\end{array}$ \\
\hline $\begin{array}{l}\text { Gemment on the } \\
\text { German translation }\end{array}$ & $\begin{array}{l}\text { The errors in this example are not limited } \\
\text { to the addition of "im Sinne von Artikel 81 } \\
\text { Absatz 1 EG-Vertrag" (in accordance with Article } \\
81 \text { paragraph 1 of the EU treaty). Rather, } \\
\text { the sense is completely distorted by the fact that } \\
\text { the full stop behind "art." was interpreted } \\
\text { as a sentence boundary. }\end{array}$ \\
\hline
\end{tabular}

Ex. 14 (legal essay).

\begin{tabular}{|l|l|}
\hline \hline source text & $\begin{array}{l}\text { Quelli sopra elencati rappresentano, in estrema } \\
\text { sintesi, gli aspetti a nostro avviso di maggior } \\
\text { rilievo della Riforma, per una più approfondita } \\
\text { disamina dei quali rimandiamo alla trattazione } \\
\text { che segue. }\end{array}$ \\
\hline target text & $\begin{array}{l}\text { Die oben aufgeführten sind, kurzum, wir glauben, } \\
\text { dass die wichtigsten Aspekte der Reform für eine } \\
\text { gründlichere Untersuchung der bezeichnen } \\
\text { wir die Diskussion, die folgt. }\end{array}$ \\
\hline $\begin{array}{l}\text { English translation of } \\
\text { source the } \\
\text { example }\end{array}$ & $\begin{array}{l}\text { Those listed above represent, in a nutshell, } \\
\text { the most important aspects of the Reform } \\
\text { in our opinion, for a more in-depth examination } \\
\text { of which we refer to the following discussion. }\end{array}$ \\
\hline $\begin{array}{l}\text { comment on the } \\
\text { German translation }\end{array}$ & $\begin{array}{l}\text { The translation makes no sense here because } \\
\text { the sentence construction was not correctly } \\
\text { interpreted. }\end{array}$ \\
\hline
\end{tabular}

Sense-changing sentence separations (xv) were a problem identified already in ex. 13 from a civil court judgment. Numerous examples from the other text types could be cited. An independent case of wrong syntactic interpretation (xvi), on the other hand, is in ex. 15. 
Ex. 15 (civil court judgment).

\begin{tabular}{|l|l|}
\hline \hline source text & $\begin{array}{l}\text { Nel corso del giudizio si sono costituiti R.S. } \\
\text { e C.S., quali eredi di G.S., dando atto } \\
\text { del sopravvenuto decesso di quest'ultimo. }\end{array}$ \\
\hline target text & $\begin{array}{l}\text { Im Laufe des Verfahrens wurden R.S. gegründet. } \\
\text { und C.S., als Erben von G.S., die dessen Tod } \\
\text { anerkennen. }\end{array}$ \\
\hline $\begin{array}{l}\text { English translation of } \\
\text { the source text } \\
\text { example }\end{array}$ & $\begin{array}{l}\text { During the proceedings, R.S. and C.S. as heirs } \\
\text { of G.S., appeared before the court and confirmed } \\
\text { his death. }\end{array}$ \\
\hline $\begin{array}{l}\text { comment on the } \\
\text { German translation }\end{array}$ & $\begin{array}{l}\text { The problem consists here in the non-recognition } \\
\text { of the tense of the verb "costituirsi" } \\
\text { and in the interpretation as a passive form } \\
\text { of the verb "costituire". As a result, instead } \\
\text { of "appear" the translation was "found". }\end{array}$ \\
\hline
\end{tabular}

A special case of syntax error is the misinterpretation of the syntax when clause elements follow after a colon (xvii; ex. 16).

Ex. 16 (statement of claim).

\begin{tabular}{|c|c|}
\hline source text & 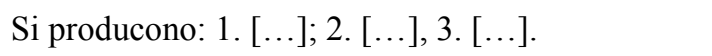 \\
\hline target text & 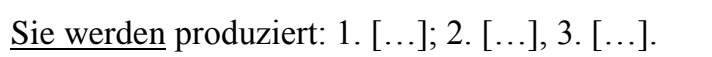 \\
\hline $\begin{array}{l}\text { English translation of } \\
\text { the source text } \\
\text { example }\end{array}$ & $\begin{array}{l}\text { The following documents are presented: } 1 .[\ldots] \text {; } \\
\text { 2. }[\ldots], 3 .[\ldots] \text {. }\end{array}$ \\
\hline $\begin{array}{l}\text { comment on the } \\
\text { German translation }\end{array}$ & $\begin{array}{l}\text { Neither DeepL Translator nor MateCat interpret } \\
\text { the words listed after the colon as a complement } \\
\text { to "produrre". Rather, the pronoun "sie" becomes } \\
\text { the subject of a passive sentence. }\end{array}$ \\
\hline
\end{tabular}

As further problems of syntactic nature, the following can be cited: wrong references (xviii; ex. 17), wrong interpretation of anaphors (xix; ex. 18), wrong word order (xx; ex. 19), tense error (xxi; ex. 20), misinterpretation of certain grammatical structures of Italian (si passivante, absolute participal constructions, position 
of the genitive attribute; xxii) (ex. 13: "della scrittura-testamento" is related to "vero e proprio disconoscimento (o mancato riconoscimento)"), wrong adjective interpretation when the adjective corresponds to a noun with an identical form (xxiii; ex. 21).

Ex. 17 (notarial real estate sale contract).

\begin{tabular}{|l|l|}
\hline \hline source text & $\begin{array}{l}\text { A tal fine, l'acquirente dichiara: - che l'immobile } \\
\text { di cui al presente atto è ubicato nel Comune } \\
\text { in cui stabilirà entro diciotto mesi dall'acquisto } \\
\text { la propria residenza; [...]. }\end{array}$ \\
\hline target text & $\begin{array}{l}\text { Zu diesem Zweck hat der Käufer eine Erklärung } \\
\text { abzugeben: - dass sich die in dieser Urkunde } \\
\text { bezeichnete Immobilie in der Gemeinde befindet, } \\
\text { in der sie innerhalb von achtzehn Monaten nach } \\
\text { dem Erwerb ihres Wohnsitzes errichtet wird; [...]. }\end{array}$ \\
\hline $\begin{array}{l}\text { English translation of } \\
\text { the source text } \\
\text { example }\end{array}$ & $\begin{array}{l}\text { To this end, the buyer declares: - that } \\
\text { the apartment referred to in this deed is located } \\
\text { in the municipality in which he will establish his } \\
\text { residence within eighteen months of purchase; } \\
\text { [...]. }\end{array}$ \\
\hline $\begin{array}{l}\text { comment on the } \\
\text { German translation }\end{array}$ & $\begin{array}{l}\text { The main error in this example is that the pronoun } \\
\text { "sie" is referred to "Immobilie" rather than } \\
\text { "Käufer". This will then transform the phrase } \\
\text { "establishment of the residence", into the phrase } \\
\text { "construction of the apartment". }\end{array}$ \\
\hline
\end{tabular}

Ex. 18 (law).

\begin{tabular}{|l|l|}
\hline \hline source text & $\begin{array}{l}\text { L'atto aziendale è predisposto dalla direzione } \\
\text { aziendale dell'Azienda Sanitaria }[\ldots] \\
\text { ed è sottoposto all'approvazione della Giunta } \\
\text { provinciale. Esso è adottato dalla direttrice/dal } \\
\text { direttore generale entro i dieci giorni successivi } \\
\text { all'approvazione da parte della Giunta } \\
\text { provinciale. }\end{array}$ \\
\hline target text & $\begin{array}{l}\text { Das Unternehmensgesetz wird von der Leitung } \\
\text { der Gesundheitsbehörde [...] ausgearbeitet und } \\
\text { bedarf der Zustimmung des Provinzialrats. } \\
\text { Er wird vom Direktor/Generaldirektor innerhalb }\end{array}$ \\
\hline
\end{tabular}




\begin{tabular}{|l|l|}
\hline & $\begin{array}{l}\text { von zehn Tagen nach seiner Annahme durch den } \\
\text { Provinzialrat angenommen. }\end{array}$ \\
\hline $\begin{array}{l}\text { English translation of } \\
\text { the source text } \\
\text { example }\end{array}$ & $\begin{array}{l}\text { The internal regulations will be drafted } \\
\text { by the management of the sanitary company [... } \\
\text { and submitted to the province government } \\
\text { for approval. Such approval will be issued } \\
\text { by the director/general director within ten days } \\
\text { of its approval by the province government. }\end{array}$ \\
\hline $\begin{array}{l}\text { comment on the } \\
\text { German translation }\end{array}$ & $\begin{array}{l}\text { The pronoun "er" is not related to the subject } \\
\text { of the sentence before. Apart from that, } \\
\text { the translation contains various terminology } \\
\text { errors, in patto } \\
\text { aziendale/Unternehmensgesetz" and "giunta } \\
\text { provinciale/Provinzialrat". }\end{array}$ \\
\hline
\end{tabular}

Ex. 19 (power of attorney).

\begin{tabular}{|c|c|}
\hline source text & $\begin{array}{l}\text { Con la presente scrittura privata, la società per } \\
\text { azioni di nazionalità tedesca denominata " } \\
\text { AG" (di seguito, la "Società") [...] nomina } \\
\text { e costituisce procuratori speciali della socièà } \\
\text { i Signori }[\ldots] \text {. }\end{array}$ \\
\hline target text & $\begin{array}{l}\text { Mit dieser privaten Vereinbarung die deutsche } \\
\text { Firma namens " } \\
\text { die "Gesellschaft") } \overline{\text { AG" }} \text { (nachfolgend } \\
\text { spezielle Staatsanwälte der Firma }[\ldots] \text { ernent }\end{array}$ \\
\hline $\begin{array}{l}\text { English translation of } \\
\text { the source text } \\
\text { example }\end{array}$ & $\begin{array}{l}\text { With this privately executed agreement, the } \\
\text { German public limited company "_ AG" } \\
\text { (hereafter the "company") appoints } \\
\text { and designates as its special attorneys Messrs: } \\
{[\ldots] \text {. }}\end{array}$ \\
\hline $\begin{array}{l}\text { comment on the } \\
\text { German translation }\end{array}$ & $\begin{array}{l}\text { The binomial "ernennt und bestellt" would have } \\
\text { to be placed before the subject "die deutsche } \\
\text { Firma", which, apart from that, was translated } \\
\text { in too a general way. A terminology error } \\
\text { is the translation of "procuratore speciale" with } \\
\text { "spezieller Staatsanwalt" ("special State } \\
\text { Prosecutor") instead of "Spezialbevollmächtigter" } \\
\text { ("special attorney"). }\end{array}$ \\
\hline
\end{tabular}


Ex. 20 (statement of claim).

\begin{tabular}{|l|l|}
\hline \hline source text & $\begin{array}{l}\text { così come saranno dimostrati nel corso } \\
\text { dell'istruttoria }\end{array}$ \\
\hline target text & $\begin{array}{l}\text { wie im Rahmen des Ermittlungsverfahrens } \\
\text { nachgewiesen wurde }\end{array}$ \\
\hline $\begin{array}{l}\text { English translation of } \\
\text { the source text } \\
\text { example }\end{array}$ & as will be proved during the inquiry phase \\
\hline $\begin{array}{l}\text { comment on the } \\
\text { German translation }\end{array}$ & $\begin{array}{l}\text { A terminology error is the translation of the Civil } \\
\text { Procedure term "istruttoria" with the Criminal } \\
\text { Procedure term "Ermittlungsverfahren". }\end{array}$ \\
\hline
\end{tabular}

\section{Ex. 21 (statement of claim).}

\begin{tabular}{|l|l|}
\hline \hline source text & La società attrice \\
\hline target text & Die Gesellschaft Schauspielerin \\
\hline $\begin{array}{l}\text { English translation of } \\
\text { the source text } \\
\text { example }\end{array}$ & The claimant company \\
\hline $\begin{array}{l}\text { comment on the } \\
\text { German translation }\end{array}$ & $\begin{array}{l}\text { The adjective "attrice" was interpreted as a noun } \\
\text { and translated as "actor". }\end{array}$ \\
\hline
\end{tabular}

Further sources of error arise from formulaic (xxiv; ex. 22) and elliptical (xxv; ex. 23) language usage.

Ex. 22 (statement of claim).

\begin{tabular}{|l|l|}
\hline \hline source text & È autentica. \\
\hline target text & Benachrichtigen Sie. \\
\hline $\begin{array}{l}\text { English translation of } \\
\text { the source text } \\
\text { example }\end{array}$ & the signature is authentic \\
\hline
\end{tabular}




\begin{tabular}{|l|l|l|}
\hline $\begin{array}{l}\text { comment on the } \\
\text { German translation }\end{array}$ & $\begin{array}{l}\text { The translation with "Benachrichtigen Sie" } \\
\text { (Please notify) does not make any sense } \\
\text { in context. }\end{array}$ \\
\hline
\end{tabular}

\section{Ex. 23 (statement of claim).}

\begin{tabular}{|l|l|}
\hline \hline source text & Con vittoria di diritti e onorari di causa. \\
\hline target text & Mit dem Sieg der Rechte und Gerichtsgebühren. \\
\hline $\begin{array}{l}\text { English translation of } \\
\text { the source text } \\
\text { example }\end{array}$ & The defendants to pay costs. \\
\hline $\begin{array}{l}\text { comment on the } \\
\text { German translation }\end{array}$ & $\begin{array}{l}\text { The meaning of the source text formulation } \\
\text { is not clear from the formulation. Anyone who } \\
\text { is unfamiliar with the conventions of the text type } \\
\text { and the mechanisms of the Italian Civil Procedure } \\
\text { can not understand it. The translation through } \\
\text { the two machine translation systems takes place } \\
\text { at the word level and is therefore } \\
\text { as incomprehensible as the source text. }\end{array}$ \\
\hline
\end{tabular}

Morphological errors (xxvi) are rare, but MateCat has a few (Ex. 24).

Ex. 24 (legal essay).

\begin{tabular}{|l|l|}
\hline \hline source text & Principio inderogabile della Riforma \\
\hline target text & Verbindlichen Bestandteil der Reform \\
\hline $\begin{array}{l}\text { English translation of } \\
\text { the source text } \\
\text { example }\end{array}$ & overriding principle of the reform \\
\hline $\begin{array}{l}\text { comment on the } \\
\text { German translation }\end{array}$ & $\begin{array}{l}\text { The adjective morphology corresponds } \\
\text { to an accusative rather than a nominative. }\end{array}$ \\
\hline
\end{tabular}

The last two categories of errors are the non-recognition of textspecific deviations from normal language usage (xxvii; ex. 25) and problems with specific drafting and text type conventions (xxviii; ex. 26). 
Ex. 25 (notarial real estate sale contract).

\begin{tabular}{|l|l|}
\hline \hline source text & $\begin{array}{l}\text { L'anno duemilasette, il giorno _ _ del mese } \\
\text { di febbraio }\end{array}$ \\
\hline target text & $\begin{array}{l}\text { Das Jahr zweitausend und sieben, der Tag _ } \\
\text { von Februar }\end{array}$ \\
\hline $\begin{array}{l}\text { English translation of } \\
\text { the source text } \\
\text { example }\end{array}$ & On the_ of February two thousand and seven \\
\hline $\begin{array}{l}\text { comment on the } \\
\text { German translation }\end{array}$ & $\begin{array}{l}\text { The typical form of the date in a notarial deed can } \\
\text { not be translated literally, but that is exactly what } \\
\text { happened in the machine translation. }\end{array}$ \\
\hline
\end{tabular}

Ex. 26 (notarial real estate sale contract).

\begin{tabular}{|l|l|}
\hline \hline Source text & $\begin{array}{l}59,99 / 1000 \text { (cinquantanove virgola novantanove } \\
\text { millesimi) }\end{array}$ \\
\hline Target text & $\begin{array}{l}59,99 / 1000 \text { (fünf Punkte neunundneuzig Punkte } \\
\text { neunundneunzig Tausendstel) }\end{array}$ \\
\hline $\begin{array}{l}\text { English translation of } \\
\text { the source text } \\
\text { example }\end{array}$ & $\begin{array}{l}59.99 / 1000 \text { (fifty nine point ninety nine } \\
\text { thousandths) }\end{array}$ \\
\hline $\begin{array}{l}\text { Comment on the } \\
\text { German translation }\end{array}$ & $\begin{array}{l}\text { Translated by "five point ninety nine point ninety } \\
\text { nine thousandths" }\end{array}$ \\
\hline
\end{tabular}

\section{Considerations on translation pedagogy}

Although examples were found where little or no post-editing was required and even if the machine translation output is better for some types of legal texts or parts thereof as shown above, the result of the Italian-German machine translation with DeepL Translator and MateCat is, overall, still insufficient. The development 
of machine translation in this regard has therefore not progressed far enough to translate legal texts without a major post-editing effort.

In a course such as Specialized Translation from Italian into German, in which students have to learn to translate legal texts from scratch, it therefore makes no sense to give post-editing of machinetranslated legal texts a bigger place in translation pedagogy. Rather, students should first be made familiar with the current limitations of machine translation. Secondly, they should be made aware of the importance of an adequate translation approach and, in particular, of acquiring the necessary legal expertise, which allows them to assess the extent to which there is a correspondence between source and target text in consideration of the specific translation situation, where the translation reads fluently, i.e. is understandable and meaningful at a first glance.

An adequate translation approach is certainly one based on the adequacy strategies defined by Prieto Ramos (2015: 19) for the translation of legal texts. These strategies provide for the following steps for each of which legal expertise becomes relevant and must be acquired in order to achieve a satisfactory translation:

(i) analysis of the translation situation, i.e. the communicative situation and the translation brief, in order to determine the general elements of strategy;

(ii) legal macro-contextualisation of translation process at the level of the legal system/s, branch/es of law and text types and genre involved in order to determine the specific elements of strategy;

(iii) source text analysis;

(iv) reformulation;

(v) revision and verification of the adequacy of the translation strategy in the light of (i) and (ii).

In particular, the errors illustrated by examples found in the translations carried out with DeepL Translator and MateCat reveal the following:

(i) The problem is located at a level well below that of the translation situation. The purpose and recipient of the translation are completely disregarded, as can be expected considering the functioning of machine translation in general and of neural machine translation in particular. The purpose and recipient of translation are, 
however, fundamental to the choice of translation strategy and they must not be overlooked when carrying out the translation.

(ii) Apart from the fact that the target texts do not reflect the legal system resulting from the specific translation situation, they are also characterized by the fact that they contain linguistic elements which have nothing to do with either the branch of law or the text type of the source text. A leap in quality can certainly be achieved by training a machine translation system with specific translation memories or by combining a) a machine translation system and b) a CAT tool with specific translation memories. However, in order to be able to assess the translation solutions which are either only partially contained, or not at all, in the translation memory and which have been purely translated with a machine translation system, the legal expertise of the translator is indispensable.

(iii) A machine translation system trained with specific translation memories or a combination of a) a machine translation system and b) a CAT tool with specific translation memories can also improve the use of formulaic and elliptical language bound to different text types. However, legal expertise is indispensable here as well.

In order to familiarize students with the current limits of machine translation and at the same time emphasize the importance of the adequacy strategies defined by Prieto Ramos (2015: 19), the author proposes at least the following combinable possibilities:

(i) An introduction to the functioning and typical errors of machine translation and an overview of the errors made by machine translation when translating legal texts of different text types into and from different legal languages in different translation situations. Purpose: To prevent the uncritical use of machine translation systems.

(ii) Comparison of the human translations, carried out within the framework of the teaching activities according to the above defined adequacy strategies, with machine translations carried out after human translations. Purpose: To sharpen awareness of the importance of the adequate translation approach, to reveal the mistakes of machine 
translation and to give an idea of the post-editing effort required. ${ }^{4}$

(iii) Carrying out a test with two comparison groups, the first of which carries out a human translation of a legal text in accordance with above defined adequacy strategies and the second of which translates the same legal text by machine and then provides for post-editing taking into account the above defined adequacy strategies. Purpose: To underline the importance of the order of the steps belonging to the adequacy strategies, since it can be assumed that a subsequent analysis of the specific translation situation, the source text and its legal background does not lead to the same results.

\section{Bibliography}

Burchardt, Aljoscha, et al. 2014. Multidimensional Quality Metrics (MQM) Definition. http://www.qt21.eu/mqmdefinition/definition-2014-08-14.html (accessed May 7, 2019).

Burchardt, Aljoscha, and Jörg Porsiel. 2017. Vorwort: Was kann die maschinelle Übersetzung und was nicht? In Maschinelle Übersetzung. Grundlagen für den professionellen Einsatz, ed. Jörg Porsiel, 11-8. Berlin: BDÜ-Fachverlag.

Castilho, Sheila, et al. 2017. Is Neural Machine Translation the New State of the Art? The Prague Bulletin of Mathematical Linguistics 108: 109-20.

Forcada, Mikel L. 2017. Making sense of neural machine translation. Translation Spaces 6/2: 291-309.

Hansen-Schirra, Silvia, et al. 2017. Post-Editing: Strategien, Qualität, Effizienz. In Maschinelle Übersetzung. Grundlagen für den

\footnotetext{
${ }^{4}$ The importance of a comparison with reference texts is also underlined by Heiss and Soffritti (2018). In addition, they point out that the entire text and the translation situation must be kept in mind when post-editing individual text parts. Moreover, they maintain that a theory-based approach is a prerequisite for high-quality translations and that post-editing that takes translation theory into account should be an essential part of translation pedagogy.
} 
professionellen Einsatz, ed. Jörg Porsiel, 176-91. Berlin: BDÜ-Fachverlag.

Heiss, Christine, and Marcello Soffritti. 2018. DeepL Traduttore e didattica della traduzione dall'italiano in tedesco. Alcune valutazioni preliminari. InTRAlinea. Special Issue: Translation and Interpreting for Language Learners (TAIL). http://www.intralinea.org/specials/article/2294 (accessed September 13, 2019).

Hutchins, W. John. 1995. Machine Translation: A Brief History In Concise History of the Language Sciences: from the Sumerians to the Cognitivists, eds. Ernst F. K. Koerner and R.E. Asher, 431-45. Oxford: Pergamon Press.

Killman, Jeffrey. 2014. Vocabulary Accuracy of Statistical Machine Translation in the Legal Context. In Third Workshop on PostEditing Technology and Practice, eds. Sharon O'Brian, Michel Simard and Lucia Specia, 85-98. www.amtaweb.org/AMTA2014Proceedings/AMTA2014Proc eedings_PEWorkshop_final.pdf (accessed May 7, 2019).

Koehn, Philipp. 2010. Statistical Machine Translation. Cambridge: Cambridge University Press.

Kyburz, Kevin. 2018. Schlägt sogar Google. Die Übersetzungsmaschine DeepL. https://techgarage.blog/schlaegt-sogar-google-dieuebersetzungsmaschine-deepl/ (accessed February 28, 2019).

Matthiesen, Aaron J. 2017. Maschinelle Übersetzung im Wandel. Die Auswirkungen von künstlicher Intelligenz auf maschinelle Übersetzungssysteme. Mit einer vergleichenden Untersuchung von Google Translate und Microsoft Translator. Berlin: epubli.

Prieto Ramos, Fernando. 2015. Quality Assurance in Legal Translation: Evaluating Process, Competence and Product in the Pursuit of Adequacy. International Journal for the Semiotics of Law - Revue internationale de Sémiotique juridique 28/1: 11-30.

Şahin, Mehmet, and Nilgün Dungan. 2014. Translation testing and evaluation: A study on methods and needs. Translation \& Interpreting 6/2: 67-90.

Van Brussel, Laura, et al. 2018. A Fine-grained Error Analysis of NMT, PBMT and RBMT Output for English-to-Dutch. In Eleventh International Conference on Language Resources and Evaluation,

3799-804. 
https://biblio.ugent.be/publication/8561558 (accessed May 8, 2019)

Wallberg, Ilona. 2017. DIN EN ISO 18587 - eine Norm über den Prozess des Posteditierens. In Maschinelle Übersetzung. Grundlagen für den professionellen Einsatz, ed. Jörg Porsiel, 160-7. Berlin: BDÜ-Fachverlag.

Werthmann, Antonia, and Andrea Witt. 2014. Maschinelle Übersetung - Gegenwart und Perspektiven. In Translation and Interpretation in Europe. Contributions to the Annual Conference 2013 of EFNIL in Vilnius, ed. Gerhard Stickel, 79-103. Frankfurt et al.: Lang.

Yates, Sarah. 2006. Scaling the Tower of Babel Fish: An Analysis of the Machine Translation of Legal Information. Law Library Journal 98/3: 481-500. 